\title{
Development of Guided Inquiry Learning to Improve the Ability of Makeup Design Using Corel Draw
}

\author{
Dindy Sinta Megasari ${ }^{1}$ Ita Fatkhur Romadhoni ${ }^{2}$, Luthfiyah Nurlaela ${ }^{3}$, Setya Cendra \\ Wibawa $^{4}$
}

\author{
1, 2, 3, Department of Home Economics, Universitas Negeri Surabaya \\ 4Department of Technology Information, Universitas Negeri Surabaya \\ *Corresponding authorE-mail: dindymegasari@unesa.ac.id itaromadhoni@unesa.ac.id
}

\begin{abstract}
The purpose of this study is to improve student skills in determining ideas that will be developed to design using corel draw. This research was conducted in the students of cosmetology study program at home economic department state university of Surabaya with a total of 30 students. Characteristics of students are ability in a heterogeneous class. This type of research is classroom action research conducted in a particular class with the aim to improve student learning outcomes learning skills. Data analysis was applied with a Likert scale modification. Significant improvement in student process skills in the learning process of Cycle I and Cycle II. Significant improvement in student process skills also influences students' mastery of concept concepts in each cycle. From the observational data in each cycle, it was found that the skills that Inquiry process skills in Cycle I were felt to be less effective, because lecturers rarely develop process skills. Future studies are suggested to consider aspects of behavioral skills in developing instruments.
\end{abstract}

Keywords: learning skills, inquiry learning, cosmetology education

\section{INTRODUCTION}

Technological developments in 2019 have led to fierce competition in all aspects of life. Such intense competition cannot be separated from all elements of human needs that are always developing every second. It also requires all elements to adjust the vision, mission and strategies according to needs, and not out of date [1]. The national education system must always develop in accordance with the needs and developments that occur at the local, national and global levels. The existence of reform efforts for a change can answer all the challenges of the development of the global era, especially for Indonesia must do so. The global era has many challenges that must be prepared and readily carried out by everyone in the realization of an increase in human resources therein. This is one of the key factors in reform, namely how to create quality human resources and have high skills and competitiveness in global competition [2]. Therefore there is a need for skills education. Lecturers in the teaching process require an interesting learning model and in accordance with the demands of current technological development including inquiry learning models. In the field of beauty there is one creative design course in which there are planning, making color plans from design inspiration, carrying out the design / production process, evaluating up to developing design marketing plans. Still rarely found in the outside world who work in the field of creative design, especially face design for the cosmetology field. Education is a natural process that takes place naturally in a human life. Especially in a family environment. Parents function as educators and children as students. In a development, human life is increasingly advanced and increasingly complex, so that family education that prioritizes the formation of personal nature, is no longer sufficient to deal with the development and progress of science and technology. Therefore, a formal educational structure was created called education in schools. Creativity can be used to predict learning success. But actually everyone is creative, to get it there needs to be training and guidance from parents and lecturers. According to [3], "creativity is not only done by people whose work demands creative thinking (as a profession), but can also be done by ordinary people in completing tasks and overcoming problems".

The purpose of this study is to improve students' skills by developing beauty design ideas that are processed using corel draw so that after graduating, these students are ready to face the changing times and work in the cosmetology creative design. 


\section{METHOD}

\section{Procedure and Materials}

This type of research is classroom action research conducted in a particular class with the aim to improve student learning outcomes learning skills [4]. This class action research was conducted at Surabaya State University, Jalan Ketintang Surabaya Building A7, 3rd Floor Computer Laboratory. This research was conducted on beauty students with a total of 30 students.

\section{Research Design}

The preparation phase is done by planning and arranging learning tools. Next is the implementation phase by applying the learning model to creative design courses. Observations are made while learning takes place, so that both are running at the same time. At this stage the researcher makes observations and records all the things that are needed and occur when the learning / implementation of the research takes place. The reflection phase is part of the end to find out the strengths and weaknesses carried out in classroom action research, data from observations of actions are explored, analyzed and carefully studied so that it can be known what needs to be eliminated and what needs to be improved and maintained [5]. This activity is a reference for planning activities in the next cycle of classroom action research.

\section{Data Analysis Technique}

The observations data of instructor activities in the application of inquiry learning model were analyzed with quantitative descriptive as a percentage, summing the average level of grouping per cycle, then converted to the value of $1=$ implemented, not finished, 2

= implemented, less systematic, 3 = implemented, less precise, 4 = implemented, finished, precise and systematic. If it meets the description standards according to the Likert scale modification [6].

\section{RESULTS AND DISCUSSION}

Observations on the performance criteria of lecturers in implementing and managing inquiry learning, observations were also made on aspects of lecturer performance in improving student process skills, the following are the results of the observer analysis summarized in Table 1 below.

Table 1 Lecturer Performance in Learning Cycle I

\begin{tabular}{|c|c|c|}
\hline No & Rated aspect & Score \\
\hline 1. & $\begin{array}{l}\text { The suitability of lecture material with aspects of the process skills } \\
\text { implemented }\end{array}$ & 4 \\
\hline 2. & The ability of lecturers to condition students to study & 3 \\
\hline 3. & The skill of asking lecturers in the learning process & 3 \\
\hline 4. & The ability of lecturers to guide students in group discussions & 3 \\
\hline 5. & $\begin{array}{l}\text { The ability of the lecturer to guide students to report the results of the } \\
\text { discussion }\end{array}$ & 3 \\
\hline 6 & $\begin{array}{l}\text { The ability of lecturers to guide students to develop face designs using Corel } \\
\text { Draw }\end{array}$ & 3 \\
\hline 7. & $\begin{array}{l}\text { The ability of lecturers to guide students in communicating the results of their } \\
\text { written work }\end{array}$ & 3 \\
\hline 8. & $\begin{array}{l}\text { The ability of lecturers to guide students in communicating the results of their } \\
\text { activities in writing }\end{array}$ & 3 \\
\hline 9 & $\begin{array}{l}\text { The ability of lecturers to guide students in summarizing the results of their } \\
\text { learning activities in writing }\end{array}$ & 2 \\
\hline 10. & $\begin{array}{l}\text { The ability of lecturers to provide answers to each student question in every } \\
\text { aspect of process skills }\end{array}$ & 3 \\
\hline \multicolumn{2}{|c|}{ Total score } & 30 \\
\hline \multicolumn{2}{|c|}{ Average } & 3,0 \\
\hline \multicolumn{2}{|c|}{ Percentage } & $75 \%$ \\
\hline
\end{tabular}

Note: 4 (very good), 3 (good), 2 (enough), 1 (less)

Obtained information that in general the performance of lecturers in improving student process skills in the first cycle can be categorized as quite adequate, the lecturer is able to guide students in conducting discussions seen in Table 1 above. Guided inquiry learning is a learning approach which applies the concept of environmental conservation in integrated science learning. This approach to learning includes plenty of uses scientific approach to gaining knowledge [7]. However, there are several aspects of lecturer performance that need to be improved in the next cycle, namely the aspect of lecturer performance in guiding students to conduct group discussions, in the implementation of discussion activities felt to be less effective, because many students ask about the steps of the discussion, even though these steps have already been explained by the lecturer. Guided inquiry learning model aims to give chance for learners to learn how to find the facts, concepts, and princip- les through direct experience, to improve science literacy and to train learners in investigating prob- lems or questions. Guided [8]. In addition, aspects of lecturer performance that need to be reminded are aspects of the 
ability of lecturers in guiding students to conclude the results of the discussion because there are still students who ask questions about the conclusions from the results of the discussions conducted. Student activity data in the first cycle of learning in this study the authors set 5 aspects of student process skills that are the target of learning. In this study there are some abilities of students who still have a small score. Among them the ability to solve problems in the classroom to determine the type of face design. Observation results related to these 5 aspects are shown in Table 2 below.

Table 2 Improving Student Process Skills in Cycle I Learning

\begin{tabular}{|c|c|c|c|c|c|c|c|}
\hline \multirow{2}{*}{ No } & \multirow{2}{*}{ Types of Process Skills } & \multicolumn{5}{|c|}{$\begin{array}{c}\text { The Intensity of Performing Process Skills for Each } \\
\text { Criteria }\end{array}$} & \multirow{2}{*}{ Average } \\
\hline & & $\mathrm{I}$ & II & II & IV & $\mathrm{V}$ & \\
\hline 1. & Discussion & $60 \%$ & $70 \%$ & $51 \%$ & $50 \%$ & $50 \%$ & $56.1 \%$ \\
\hline 2. & Formulate the problem & $60 \%$ & $55.5 \%$ & $55.1 \%$ & $50.3 \%$ & $50.3 \%$ & $50.1 \%$ \\
\hline 3. & Composing Hypothesis & $71.4 \%$ & $57.1 \%$ & $66.6 \%$ & $66.6 \%$ & $83.3 \%$ & $60 \%$ \\
\hline 4. & Do a trial run & $22.1 \%$ & $42.8 \%$ & $40 \%$ & $30 \%$ & $30 \%$ & $32.9 \%$ \\
\hline 5. & Conclude & $42.8 \%$ & $28.5 \%$ & $30 \%$ & $22.6 \%$ & $22.5 \%$ & $30.8 \%$ \\
\hline Total & & $53.3 \%$ & $42.2 \%$ & $50.6 \%$ & $47.3 \%$ & $48.6 \%$ & $47.6 \%$ \\
\hline
\end{tabular}

Information obtained in Table 2 shows that the improvement of students' process skills began to be seen and an increase in the initial skills possessed by students, which reached an average value of $50.4 \%$ with quite good category but there are several aspects of student process skills that still need to be improved in the next cycle, namely on the type of concluding skills, because students have not been able to draw their own conclusions from the results of the discussion on the implementation of drawing sets in accordance with the material and concepts learned, also on the skills of communicating verbally, in addition to being able to support lecturers in giving opportunities to students to communicate the results of their activities students also seen as lacking the initiative to communicate the results of their discussions. Due to the fulfillment of the percentage of aspects of usage convenience, benefits, and efficiency of time is good, it can be concluded that the student worksheet using guided inquiry model is categorized as practical [9]. In the next cycle, the focus of action in terms of mastery of concepts is to increase the achievement of average grades and reduce the number of students who still score less than 70 .

It is known that in general the improvement of students' process skills can be categorized as good, an increase in process skills in the type of communicating verbally, and inferring skills. As targeted in cycle I, in addition to reflecting on the performance of lecturers in providing opportunities and passing time in communicating the results of the discussion. In the aspect of concluding students can conclude from the results of the discussion with a series of questions on student worksheets and lecturer guidance. Students that were able to provide correct answers and remember exercise responses for given factors typically paid attention to the specific value during the experiment or they worked afterward with the analysis of or illustrations of the response in their report [10]. The Improved process skills can be seen in Table 3 below.

Table 3. Improved Student Process Skills in Cycle Learning II

\begin{tabular}{llllllll}
\hline \multirow{2}{*}{ No } & \multirow{2}{*}{ Types of Process Skills } & \multicolumn{5}{c}{ The Intensity of Performing Process Skills for Each } & \multirow{2}{*}{ Average } \\
\cline { 3 - 6 } & & I & II & II & IV & V & \\
\hline 1. & Discussion & $71.4 \%$ & $57.1 \%$ & $57.1 \%$ & $42.8 \%$ & $57.1 \%$ & $57.1 \%$ \\
\hline 2. & Formulate the problem & $57.1 \%$ & $57.1 \%$ & $42.8 \%$ & $57.1 \%$ & $42.8 \%$ & $51.3 \%$ \\
\hline 3. & Composing Hypothesis & $83.3 \%$ & $66.6 \%$ & $66.6 \%$ & $66.6 \%$ & $83.3 \%$ & $73.2 \%$ \\
\hline 4. & Do a trial run & $42.8 \%$ & $42.8 \%$ & $83.3 \%$ & $66.6 \%$ & $66.6 \%$ & $60.1 \%$ \\
\hline 5. & Conclude & $66.6 \%$ & $83.3 \%$ & $42.8 \%$ & $66.6 \%$ & $66.6 \%$ & $30.8 \%$ \\
\hline Total & & & $61.3 \%$ & $58.5 \%$ & $59.9 \%$ & $63.2 \%$ & $61.1 \%$ \\
\hline
\end{tabular}


The learning process of students looks quite enthusiastic and eager to learn and conduct discussions as well as in cycle I. Student activity can support learning, so learning can run well. Although in the learning flow the concentration of students starts to decrease because learning begins at noon. Based on the results of observations on the process skills of students in the second cycle of learning has increased significantly, especially the type of process skills that are targeted in the first cycle, namely: verbally communicating and concluding. As a result, the use of the POGIL strategy for the phar- macologic concepts represented a more significant shift in class activities and approach to solving problems [11]. Increasing the ability of lecturers to make scientific-based learning designs can be seen improvement in Figure 1 below.

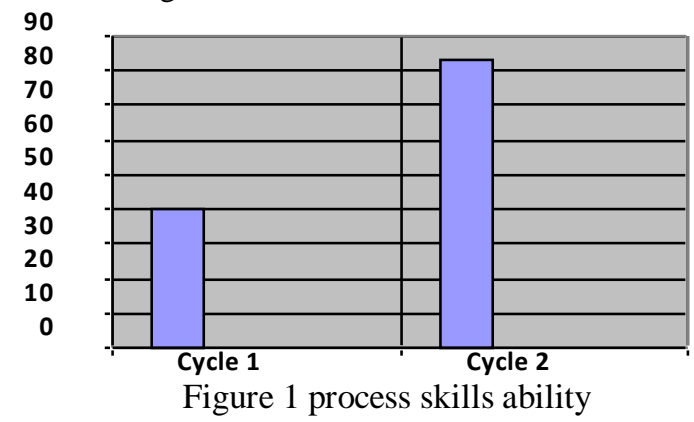

After the second cycle of learning has been completed, the researcher and the observer (lecturer) agree to reflect and evaluate the overall learning actions that have been implemented. In the discussion with the observer (lecturer), observation of the results of the observations, results of the reflection and orientation of the objectives of the implementation of classroom action research are sourced from the preparation and implementation data of the first cycle, and the second cycle, which is globally informed that the researcher and the observer agree that the research implementation Class action, although the first time it has been carried out, has provided valuable experience and results for efforts to improve the quality of learning, especially in the course of Inquiry the topic of designing faces using Corel Draw. According to [12] where problems drive learning in Problem-based learning, [13][14][15] suggest that inquiry-based classrooms are driven by questions that focus and frame inquiries. [16] [17] describe four different inquiry stages that students with novice to expert levels of problem solving skills can accomplish: (1) confirmation; structured; (3) guided; and (4) open.

The most memorable experience for researchers was that in general classroom action research that was conducted for the first time the researcher turned out to be quite good, although in cycle one it was felt to be less effective, but in cycle II there was a significant increase in lecturer performance and student performance. In addition, lecturers also gain new experiences, that learning feels more effective. So, the application of learning and assessment methods must be prepared carefully with the carrying capacity of teaching aids and adequate Student Worksheets. [18] said that there were four main sources of self-efficacy beliefs, namely mastery experiences, vicarious experience, social persuasion, and physical and emotional states. The experiences include increasing insight and skills in developing and implementing lesson plans described in Figure 2 below.

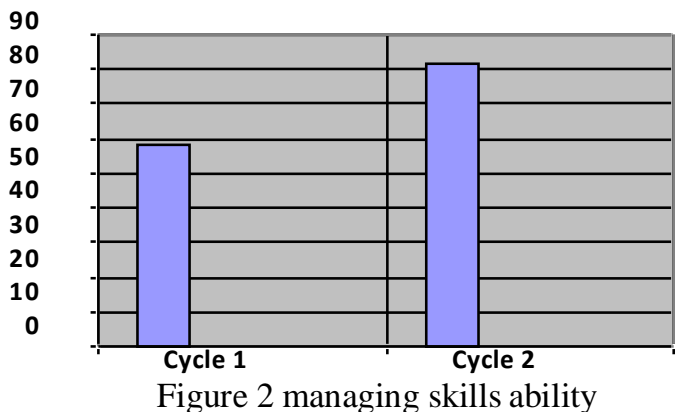

In the context of mathematics learning, the mastery experience of students can be improved when students are guided in solving problems. Problems that were assigned to be solved by students in learning by using GDL-BTCC materials were challenging problems and were within the reach of students' cognitive development. The success of students solving problems would increase students' self-efficacy beliefs [19]The constraints felt by the lecturers have not been able to be optimized properly during class action research are 
limitations in improving students' communication process skills, especially in asking questions and other obstacles are the limited time allocation on learning. Overall student cooperation starting from cycle I to II, which is intended to assess student collaboration in group work can be categorized as sufficient. Because of the consideration of time and results that have been achieved, researchers and observers (peer lecturers) agreed to first stop the implementation of this research.

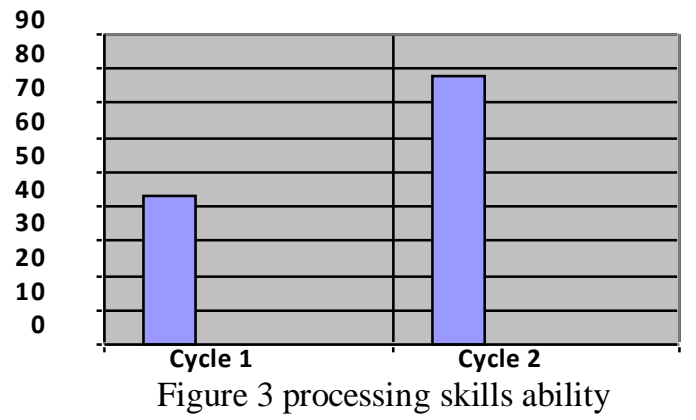

The main focus of the action research conducted by researchers is to improve students' process skills through the application of Inquiry learning methods. In addition, the achievement of improving the process skills is expected to have a positive effect on student learning outcomes in the form of mastering the concept of designing round and oval faces using Corel Draw. However, while effects research on the corel design initiative has indicated positive experiences for students, more granular situated understanding is needed of student inquiry and discovery-based processes, because other research work by scholars has suggested that the program is not conducive to all students; intrinsic motivation is positively associated with student learning outcomes [20] [21].The learning settings are carried out through formal learning which is usually carried out through theoretical and practical learning at the Multimedia Computer Laboratory of the home economic department, which consists of three phases: initial activities, core activities, and final activities. The results of observations on average improvement in student process skills are shown in Table 4 below.

Table 4. Improved Student Process Skills in Learning Cycle I and Cycle II

\begin{tabular}{lllll}
\hline \multirow{2}{*}{ No } & Types of Process Skills & \multicolumn{2}{c}{ Score } & \multirow{2}{*}{ Enhancement } \\
\cline { 3 - 4 } & & I & II & \\
\hline 1. & Discussing & $56,1 \%$ & $57,1 \%$ & $1 \%$ \\
\hline 2. & Asking question & $50,1 \%$ & $51,3 \%$ & $0,98 \%$ \\
\hline 3. & Cooperating & $69 \%$ & $73,2 \%$ & $4.2 \%$ \\
\hline 4. & Communicating & $32,1 \%$ & $64,4 \%$ & $23,3 \%$ \\
\hline 5. & Concluding & $30,8 \%$ & $65,1 \%$ & $34,3 \%$ \\
\hline \multicolumn{2}{l}{ Average } & $47,6 \%$ & $61,4 \%$ & $13,8 \%$ \\
\hline
\end{tabular}

It can be seen in Table 4 above that there was a significant increase in students' process skills in the learning process of Cycle I and Cycle II. Significant improvement in student process skills also influences students' mastery of concept concepts in each cycle. From the observational data in each cycle, it was found that the skills that Inquiry process skills in Cycle I were felt to be less effective, because lecturers rarely develop process skills. In cycle II the overall process skills of students are more effective than cycle I. That students who are usually less active in learning before CAR, are able to initiate discussions. So it can be concluded that with the process skills students can be active in learning and take learning experiences and gain meaningful learning experiences. In light of the researcher's observations, it is believed that students' active participation in lessons by taking part in activities and answering the questions asked by the researcher within and between group discussions made positive contributions to the development of their critical thinking levels [22]. Based on the whole, it can be concluded that the use of Inquiry learning methods can improve student skills, teaching aids and student work scars in each cycle of action has a positive effect on the learning outcomes of concept mastery and student process skill performance on face design material using Corel Draw.

\section{CONCLUSION}

Lecturer activities in managing the classroom using Inquiry learning learning obtains some input including time-related. So that researchers make improvements in 
[9] D. Dewantara, S. M. Hasan, and S. Annur, "Inquiry Learning Model To Train Student' S Scientific Attitude," Vol. 7, No. 1, Pp. 19-26, 2018.

classroom observations of student activities during the learning process of Inquiry underwent changes that had so far focused on the teacher center switching to the student center. So that there are still some obstacles in adjusting the learning process using inquiry. Student learning outcomes after the application of Inquiry learning has increased, although not yet significantly. This happens because of time constraints in the learning process. Student responses to the Inquiry learning model during the learning process took place various responses from students. Generally acceptable, but needs to be developed.

\section{REFERENCES}

[1] M. Pedaste, M. Mäeots, L. A. Siiman, T. De Jong, Z. C. Zacharia, and E. Tsourlidaki, "Phases of inquiry-based learning: Definitions and the inquiry cycle," Educ. Res. Rev., vol. 14, pp. 47-61, 2015.

[2] B. K. Prahani, I. Limatahu, L. Yuanita, and M. Nur, "Effectiveness Of Physics Learning Material Through Guided Inquiry Model To Improve Student' S Problem Solving," vol. 4, no. 12, pp. 231-242, 2016.

[3] Ş. Şen and A. Yılmaz, "The Effects Of Process Oriented Guided Inquiry Learning Environment On Students , Self-Regulated Learning Skills," vol. 66, 2015.

[4] D. Lake and J. Wendland, "Practical, Epistemological, and Ethical Challenges of Participatory Action Research: A CrossDisciplinary Review of the Literature," vol. 22, no. 3, pp. 11-42, 2018

[5] E. Ural, "The Effect of Guided-Inquiry Laboratory Experiments on Science Education Students ' Chemistry Laboratory Attitudes , Anxiety and Achievement," vol. 4, no. 4, pp. 217-227, 2016.

[6] P. Greathouse, "Effects of a positive youth development approach to literacy through young adult literature in the secondary remedial reading class: an action research study," no. March, 2017.

[7] A. Saefullah et al., "Efforts to Improve Scientific Literacy of Students through Guided Inquiry Learning Based on Local Wisdom of Baduy "s Society," vol. 3, no. 2, pp. 84-91, 2017.

[8] M. I. S. Putra, W. Widodo, and B. Jatmiko, "Jurnal Pendidikan IPA Indonesia The Development Of Guided Inquiry Science Learning Materials To Improve Science Literacy Skill Of Prospective Mi Teachers," vol. 5, no. 1, pp. 83-93, 2016.
L. Nybo And M. May, "Effectiveness Of Inquiry-Based learning in an undergraduate exercise physiology course," pp. 76-80, 2019.

[11] R. Soltis, N. Verlinden, N. Kruger, A. Carroll, and T. Trumbo, "Process-Oriented Guided Inquiry Learning Strategy Enhances Students ' Higher Level Thinking Skills in a Pharmaceutical Sciences Course," vol. 79, no. 1, pp. 1-8, 2015.

[12] K. H. Cattaneo, "Telling Active Learning Pedagogies Apart : from theory to practice,"

[13] vol. 6, no. 2, pp. 144-152, 2017.

[14] I. Articles, "International Journal of Active Learning," vol. 3, no. 2, pp. 110-116, 2018.

[15] S. Almuntasheri, R. M. Gillies, and T. Wright, "The Effectiveness of a Guided Inquiry- based , Teachers , Professional Development Programme on Saudi Students 'Understanding of Density," vol. 27, no. 1, pp. 16-39, 2016.

[16] B. Danker, "Using Flipped Classroom Approach to Explore Deep Learning in Large Classrooms," vol. III, no. I, pp. 171-186, 2015.

[17] I. Bagus and N. Sudria, "Effect of Kolb' s Learning Styles under Inductive GuidedInquiry Learning on Learning Outcomes," vol. 11, no. 1, pp. 89-102, 2018.

[18] S. Purkayastha, A. K. Surapaneni, P. Maity, and A. S. Rajapuri, "Critical Components of Formative Assessment in Process-Oriented Guided Inquiry Learning for Online Labs," vol. 17, no. 2, pp. 79-92, 2019.

[19] S. Avsec, S. Kocijancic, S. Journal, N. January, S. Avsec, and S. Kocijancic, "International Forum of Educational Technology \& Society A Path Model of Effective Technology-Intensive Inquiry-Based Learning Published by : International Forum of

[20] Educational Technology \& Society A Path Model of Effective Technology-Intensive Inquiry-Based Learning," vol. 19, no. 1, pp. 308-320, 2016.

[21] H. H. Hu, B. Knaeble, and C. Mayfield, "Results from a Survey of Faculty Adoption of Process Oriented Guided Inquiry Learning ( POGIL ) in Computer Science," pp. 186-191, 2016.

[22] R. B. Reynolds, "Relationships Among Tasks, Collaborative Inquiry Processes , Inquiry Resolutions , and Knowledge Outcomes in Adolescents during Guided Discovery- Based Game Design in School," 2016.

[23] S. D. Fatmaryanti, "Magnetic force learning 
with Guided Inquiry and Multiple Representations Model ( GIMuR ) to enhance students ' mathematics modeling ability," vol. 19, no. 1, pp. 1-22, 2018.

[24] M. Duran, "The effect of the inquiry-based learning approach on student, $\mathrm{s}$ critical thinking," vol. 12, no. 12, pp. 2887-2908, 2016. 